\title{
Gender Representation of Athletes in Finnish and Swedish Tabloids
}

\author{
A quantitative and qualitative content analysis \\ of Athens 2004 and Turin 2006 Olympics coverage
}

Antti Laine

\begin{abstract}
The study examines quantitatively and qualitatively gender representation in Finnish and Swedish tabloids' sports coverage during Athens 2004 summer and Turin 2006 winter Olympics. Several media studies argue that sports journalism marginalises women's sports and sexualises female athletes. The results of this study show that male athletes received more coverage than female athletes in every tabloid, but when the number of domestic participants and their level of success were considered, neither country's tabloids quantitatively marginalised women's sports. Qualitative analysis found that research stereotypes showing trivialisation and sexualisation of female athletes were incorrect, with the exception of Finnish tabloids representations of female athletes participating in sports that are considered masculine. For the most part, female athletes were represented in the same way as male athletes. However, it should be emphasised that the material is limited to Olympics coverage: during such major sporting events women are treated more equally, particularly quantitatively.
\end{abstract}

Keywords: sports journalism, sports media, gender, tabloids, content analysis, Olympics

\section{Introduction}

The media disseminates "re-presentations," which are not passive reflections of the subject. For example, when writing a story the journalist re-presents the subject, that is to say presents it again. In this context, representing refers to the process of generating impressions and representations refer to the results of that process (Pirinen 2006: 22). This study examines gender representations in newspaper sports coverage. Both the amount and the nature of coverage are studied.

The study is based on comparative research frame between Finnish and Swedish printed tabloid newspapers. As both printed papers and their websites are taken into consideration, tabloids are the most read newspapers in both studied countries. Those are major opinion builders, and in addition to news and entertainment sports is their third key content. The importance and proportion of sports pages in tabloids is bigger than in other Finnish and Swedish newspapers (Laine 2011). Thus it is important to study sports coverage in tabloids. One important topic is portrayal of gender. By examining the relationships between sports and gender we can identify societal norms and values 
as well as social structures on which the gender system is constructed (Koivula 2000). The comparative research frame between neighbouring countries Finland and Sweden has been chosen, because according to researchers preliminary understanding, Swedish sports media has altogether taken women sports more seriously than Finnish sports media in the $21^{\text {st }}$ century. Olympics have been chosen to research subject, because Olympics coverage offer comparable data for comparative research frame.

Numerous North American and British studies have shown that women's sports clearly receive less coverage in sports media than men's. With the exception of major sports events, coverage of women's sports accounts for at most 15 per cent and often less than 10 per cent of coverage regardless of the media or study. Women's sports are given proportionally more space in newspapers than air time on television. (See e.g., Brookes 2002: 128; Duncan \& Messner 2005; Eastman \& Billings 2000; Lumpkin 2009; Messner et al. 2003.) Research reports published about Finnish and Swedish sports media are similar (see e.g., Pirinen 2006: 37-41; Wallin 1998: 86-93).

The visibility of women's sports in the media has increased over recent decades, but there is still a long way to go before the amount of media coverage devoted to women's sports is proportionate to the number of women who participate in sports (see e.g., Bernstein 2002; Brookes 2002: 123-125; Wallin 1998: 86-93). Some recent studies demonstrate that the coverage of women's sports has lately actually declined. For example in a longitudinal (1989-2014) North American research project the coverage of women's sports in televised news media was the lowest ever in two latest (2009 and 2014) data collections (Cooky et al. 2013; 2015).

At the same time, numerous media studies demonstrate one significant exception: in coverage of major sports events like Olympics, the share of coverage devoted to women is significantly greater than usual in proportion to men. In some cases, the share between sexes may be almost equal. However, it is more typical for quantitative differences to narrow during major competitions, but male athletes are still clearly more covered (see e.g., Brookes 2002: 128; Duncan \& Messner 2005; Pirinen 2006: 39-40).

Pirinen (2006) addresses marginalisation of women's sports by which she means the various ways that space can be allocated to make women's sports appear invisible and leave them in the shadow of men's sports. The ideological consequence of marginalisation is the representation of women as second rate, which is reinforced in sports. This second-rate status is cultivated by trivialising female athletes. Trivialising refers to the various ways in which women taking part in sports can be made to look comical, mediocre or of little value. (Pirinen 2006: 37-41; see also Cooky et al. 2013; Duncan \& Messner 2005.)

According to Koivula (1999; 2001), female athletes are portrayed as fragile, sexy and lacking in performance ability. In the hierarchy, characterisations that sexualise appearance come before characterisations of athletic ability. Men are first and foremost athletes, who are portrayed as skilled, strong, aggressive and fast. Female athletes are referred to by their last names significantly more often than men, and women's sports events are referred to by gender more often than men's. These are throwbacks to a historically entrenched gender system and its ideologies that are reflected in today's sports media. Good example of the preservation of the patriarchal gender system is the division of sports into masculine and feminine, appropriate for men and for women. There are also sports that are considered gender-neutral. (Koivula 1999; 2001.) 
Many sports that are considered appropriate for women are individual sports. They are seen as more acceptable for female athletes than team sports (Koivula 1999). In particular, team ball sports that are extensively covered by the media have generally been classified as men's sports. Sports mentioned in research documentation as appropriate for women include figure skating, track and field, tennis and gymnastics. Women receive more visibility when competing in sports considered appropriate for women (see e.g., Crossman et al. 2007; Duncan \& Messner 2005). However, examination of women's sports media representations based only on classification of the sport is problematic: the distribution of sports in Olympics coverage depends on numerous factors, including national traditions and the number of domestic participants as well as their success (Markula 2009).

Such contextual factors have been taken into consideration in this study, which is also one of the contributions this study brings to this field of sports media studies. Other central targets are to cross traditionalistic gender boundaries and to bring both diversified understanding and openness to this research field. That has been recommended for example by Rowe (1998) and Larsson (2003). Even though gender representations have been studied widely, all scholars have not been pleased with the way representations have been approached. Rowe (1998) has argued studies should give more consideration to the diversity of masculinity and femininity and avoid following a predefined script in reporting conclusions.

\section{Research Objectives}

The research objectives include two entireties, the quantitative and qualitative examination of gender representation in sports journalism during Athens 2004 summer and Turin 2006 winter Olympics. Those Olympics are chosen in order to be able to utilise large readily available and thoroughly measured data used in an extensive in Finnish published sports media research (Laine 2011). Both objectives include a country-specific comparative framework. The research entireties are:

1. How much coverage is devoted to men's and women's sports in Finnish and Swedish newspapers? What are the quantitative differences between Finnish and Swedish coverage of men's and women's sports?

2. What kind of gender representations appear in Finnish and Swedish newspapers? How do gender representations in Finnish and Swedish newspapers differ?

\section{Research Material and Methodological Approaches}

The research material is composed of printed versions of Finnish and Swedish tabloid newspapers. The material is divided into two entireties, quantitative and qualitative newspaper data. Statistical analysis of quantitative newspaper material is referred to as quantitative content analysis, and analysis of qualitative newspaper material as qualitative content analysis.

Content analysis has been originally used mainly in quantitative research of journalism. At present content analysis is broadly defined as a research method by which replicable and valid conclusions of research materials can be made (Krippendorff 2004: 
18). Definition indicates a change of content analysis into an umbrella concept for a wide range of analysis methods in several field of research. Quantitative research designs have been joined by qualitative research designs (see Titscher et al. 2000: 55). At the same time, the distinguishing terminological details of research framework have been linked to the concept of content analysis. One suitable example is Krippendorff's widely cited piece Content Analysis (1980), where quantitative and qualitative content analyses are more clearly distinguished from each another in the second edition (2004) than in the first edition (see Krippendorff 2004: 87-88).

While the terminology distinction between quantitative and qualitative research methods is justified, it should be noted that analysis methods are frequently intertwined with each other in practice. The phenomena under study often contain both quantitative and qualitative aspects, just as the research process involves qualitative and quantitative phases (see e.g., Flick 2009: 24-30).

\section{Quantitative Newspaper Material and its Analysis}

Quantitative newspaper material is composed of the front pages and sports sections of two Finnish tabloids (Iltalehti and Ilta-Sanomat) and two Swedish tabloids (Aftonbladet and Expressen) containing coverage of the Athens 2004 Summer Olympics and the Turin 2006 Winter Olympics. Newspaper material from Athens 2004 is from the period beginning one day before the opening ceremony and ending two days after the closing ceremony (12.-31.8.2004). Newspaper material from Turin 2006 is from the period beginning two days before the opening ceremony and ending two days after the closing ceremony (8.-28.2.2006). The amount of quantitative newspaper material, counted in pages, is 1,750 . Figures specified by Olympics, country and newspaper are shown in Table 1.

Table 1. Number of Pages in Quantitative Newspaper Material

\begin{tabular}{lccr} 
& Athens 2004 & Turin 2006 & Total \\
\hline Aftonbladet & 217 & 316 & 533 \\
Expressen & 221 & 329 & 550 \\
Iltalehti & 158 & 192 & 351 \\
Ilta-Sanomat & 158 & 158 & 316 \\
Swedish newspapers & 438 & 645 & 1,083 \\
Finnish newspapers & 317 & 350 & 667 \\
Total & $\mathbf{7 5 5}$ & $\mathbf{9 9 5}$ & $\mathbf{1 , 7 5 0}$ \\
\hline
\end{tabular}

Using the measurement method developed (Laine 2011) it is possible to diversely measure and classify sports content in the tabloid newspapers. The measurement method includes 22 story variables and seven photo variables.

In quantitative analysis three variables for story and photo content classification have been used along with the method's source and identification variables. Variables for story and photo content classification are same: athlete, athlete's gender and the size of the story/photo. All photos and captions have been included in the stories when applying the story variables. With the exception of graphics and headshots of the reporters, all photos have been measured and coded separately in the photo variables. 
All quantitative newspaper material is classified and measured with selected variables. Analysis is based on comparison of relative frequencies of the size of stories and photos. The measurements have been performed in square centimetres $\left(\mathrm{cm}^{2}\right)$. The number of pages has been used as the ratio scale. Conversion of square centimetres to number of pages gives a clearer overall picture and provides comparability, as each newspaper uses the page size A3.

As the data contain all the newspaper material from studied Olympics, calculating P-value was not necessary. The reliability of the measurement method was tested by repeating the coding on a randomly selected set of data materials several months later. It was perfectly consistent. Data measurement principles and classification rules have thus been sufficiently detailed, as well as clearly separated.

\section{Qualitative Newspaper Material and its Analysis}

A core group of subjects in newspaper material were defined for use in qualitative analysis by selecting a sufficient amount of subject matter from quantitative newspaper material that depicted the phenomenon studied as comprehensively as possible and met the criteria for comparability established for qualitative analysis. The criteria for comparability were established using basic points of comparison between Finland and Sweden. The subject matter that met these criteria 1) covered a universal subject (e.g., foreign athletes) the reporting of which was not affected by interests specific to the countries being studied, 2) covered domestic athletes from comparable standpoints, 3) were covered by at least one Finnish and one Swedish paper and 4) received comparable coverage in the papers. The subject matter had to meet one of the first two criteria, and both criteria three and four.

Quantitative newspaper material included numerous subjects that met comparability criteria. Six of these were chosen as the core group of subjects to be used in qualitative analysis. Quantitative analysis was the central tool in selection of the material. In practice, four variables included in the quantitative measurement method were utilised: the subject area of the story, the sport covered, the athlete covered and the athlete's gender. Table 2 presents the core group of subjects that were selected for qualitative analysis.

Table 2. Core Group of Subjects Used in Qualitative Analysis of Newspaper Material

Athens 2004
Konstantinos Kenteris and Ekaterini Thanou doping incident
Gymnast Svetlana Khorkina
Men's marathon incident (protester pushed aside the leading runner with around
seven kilometres remaining)
Compiled reports as well as follow-up assessments and compiled analyses of domes-
tic or domestic and foreign athletes
Turin 2006
Men's hockey
Women's hockey

Qualitative newspaper material was compiled from material topologies contained in the core group of subjects. Material topologies mean individual stories and story packages 
that best represent the core group of subjects. Thus purposive sampling was conducted by selecting particularly typical cases from the core group of subject (see Flick 2009: 122). Condensing the core group of subjects into material topologies was unavoidable, as many subject areas were too broad. For example, the papers contained a total of 406 pages of hockey coverage. Selection of material topologies was guided by comparability criteria. Table 3 presents the qualitative newspaper material sorted by paper and country.

Table 3. Qualitative Newspaper Material from Athens 2004 and Turin 2006

\begin{tabular}{lcccc} 
& $\begin{array}{c}\text { Stories } \\
\text { Number }\end{array}$ & \multicolumn{2}{c}{$\begin{array}{c}\text { Story packages } \\
\text { Number }\end{array}$} & $\begin{array}{c}\text { Photos } \\
\text { Number }\end{array}$ \\
\hline Aftonbladet & 77 & 29 & 40.9 & 229 \\
Expressen & 94 & 38 & 38.9 & 230 \\
Iltalehti & 48 & 26 & 21.1 & 84 \\
Ilta-Sanomat & 56 & 21 & 20.9 & 59 \\
Swedish newspapers & 171 & 67 & 79.8 & 459 \\
Finnish newspapers & 104 & 47 & 42.0 & 143 \\
Total & $\mathbf{2 7 5}$ & $\mathbf{1 1 4}$ & $\mathbf{1 2 1 . 8}$ & $\mathbf{6 0 2}$ \\
\hline
\end{tabular}

The total number of pages in the qualitative newspaper material was 121.8 (Table 3). This is seven per cent of the quantitative newspaper material (1,750.4 pages). Story packages in Swedish papers were clearly more extensive than those about the same subjects in Finnish papers, so the number of individual stories and photos in the Swedish papers was also larger (Table 3). From the standpoint of the qualitative framework this is not significant, as there was sufficiently comparative material from papers in both countries.

The aim of the qualitative content analysis was to systematically describe the meaning of the material (see Schreier 2012: 3). In practice, qualitative content analysis of the newspaper material meant systematic close reading, summarising the material in writing and analysing the summarised material. The multiphase process was steered by the two research objectives defined.

The written summary of the texts containing gender representations came to some over 60 pages (font 12 and spacing 1,5). The material contained an extensive and varied sample of the characteristics of gender representations and examples of observable country-specific differences. The analysis was continued by classifying and comparing them. The analysis progressed in phases, structuring and further narrowing of the summarised material. The analysis focused on text. Qualitative analysis of photos was limited to comparative material supplementing the scope of the analysis.

The qualitative newspaper analysis meets several defined virtues of reliability criteria in qualitative research, for example methodological triangulation and an explanation of the solutions made at various stages in the research process (see Steinke 2004). The individual components of reliability are included in the study design, implementation and reporting of the pervading overall reliability - and thus not reported more closely in this context. 


\section{Quantitative Research Results}

Stories

All papers published more stories about male than female athletes in both the Athens 2004 and Turin 2006 material. The difference between coverage of male and female athletes in Swedish papers was, however, significantly smaller than in Finnish papers.

Because many large and regularly-published items (e.g., schedules of Olympics events and television programme listings) were classified as covering both genders, it is reasonable to limit the comparison to male athlete and female athlete classifications. In the Athens 2004 material, 55 per cent of those stories in Swedish papers were about men and 45 per cent about women. In Finnish papers, 74 per cent of those stories were about men and 26 per cent about women. (Table 4.) The gender distribution in coverage of the Athens 2004 Olympics was also found to correspond to similar studies that used Finnish and Swedish newspapers as material (Lehtinen 2006: 22; Tolvhed 2010). The percentage of stories about male athletes in both Swedish and Finnish newspapers was higher in the Turin 2006 material relative to the Athens 2004 material. In Swedish papers, 62 per cent of stories were about men and 38 per cent about women. In Finnish papers, 78 per cent of stories were about men and 22 per cent about women. (Table 4.)

Table 4. Gender of Athletes in Stories in Quantitative Newspaper material, Athens 2004 and Turin 2006

\begin{tabular}{lccclccc} 
& \multicolumn{3}{c}{ Swedish (\%) } & & \multicolumn{3}{c}{ Finnish (\%) } \\
Gender & $\mathbf{2 0 0 4}$ & $\mathbf{2 0 0 6}$ & Total & Gender & $\mathbf{2 0 0 4}$ & $\mathbf{2 0 0 6}$ & Total \\
\hline Male athlete & 55 & 62 & 60 & Male athlete & 74 & 78 & 76 \\
Female athlete & 45 & 38 & 40 & Female athlete & 26 & 22 & 24 \\
Total & $\mathbf{1 0 0}$ & $\mathbf{1 0 0}$ & $\mathbf{1 0 0}$ & Total & $\mathbf{1 0 0}$ & $\mathbf{1 0 0}$ & $\mathbf{1 0 0}$ \\
\hline
\end{tabular}

\section{Photos}

The proportion of male and female athletes in photos was about the same as in stories (compare Eastman \& Billings 2000). Based on an analysis limited to the male and female athlete classifications, when both sets of material were added together, 59 per cent of photos published in Swedish papers showed male athletes and 41 per cent female athletes. In Finnish papers the percentage of male athletes was 73 per cent and female athletes 27 per cent. (Table 6.)

Table 6. Gender of Athletes in Photos in Quantitative Newspaper Material, Athens 2004 and Turin 2006

\begin{tabular}{lccclccc} 
& \multicolumn{3}{c}{ Swedish (\%) } & & \multicolumn{3}{c}{ Finnish (\%) } \\
Gender & $\mathbf{2 0 0 4}$ & $\mathbf{2 0 0 6}$ & Total & Gender & $\mathbf{2 0 0 4}$ & $\mathbf{2 0 0 6}$ & \multicolumn{1}{c}{ Total } \\
\hline Male athlete & 56 & 60 & 59 & Male athlete & 70 & 76 & 73 \\
Female athlete & 44 & 40 & 41 & Female athlete & 30 & 24 & 27 \\
Total & $\mathbf{1 0 0}$ & $\mathbf{1 0 0}$ & $\mathbf{1 0 0}$ & Total & $\mathbf{1 0 0}$ & $\mathbf{1 0 0}$ & $\mathbf{1 0 0}$ \\
\hline
\end{tabular}




\section{Amount of Coverage of Male and Female Athletes in Proportion to the Number of Athletes and their Success}

Newspaper coverage in both countries focused on domestic athletes, and domestic medallists in particular were given high-visibility coverage. When analysis of gender distribution in coverage is limited to domestic athletes, two central factors affecting the amount of coverage emerge: the number of domestic athletes who participated in the event and their success.

In the Athens 2004 material in Swedish papers, 49 per cent of domestic athletes' coverage was about men and 51 per cent about women. Of the Swedish athletes who participated in the Olympics, 55 per cent were men and 45 per cent women. In the Turin 2006 material in Swedish papers, 60 per cent of domestic athletes' coverage was about men and 40 per cent about women. The number of male and female Swedish athletes who participated in the Olympics was exactly the same. In the Athens 2004 material in Finnish papers, 74 per cent of domestic athletes' coverage was about men and 26 per cent about women. Of the Finnish athletes who participated in the Olympics, 68 per cent were men and 32 per cent women. In the Turin 2006 material in Finnish papers, 81 per cent of domestic athletes' coverage was about men and 19 per cent about women. Of the Finnish athletes who participated in the Olympics, 67 per cent were men and 33 per cent women.

The results showed that in Swedish papers the gender distribution of domestic athletes' coverage in both the Athens and Turin material was very similar to the gender distribution of domestic athletes who participated in the Olympics. In Finnish papers, more coverage was devoted to male domestic athletes than female domestic athletes in proportion to the gender distribution of Finnish participants. However, with regard to Finnish papers it is important to note that the majority of Finnish medallists ${ }^{1}$ were male. In the Athens 2004 Olympics, Finnish athletes won two silver medals. Both medallists, shotgun shooter Marko Kemppainen and wrestler Marko Yli-Hannuksela, were men. Coverage of them made up more than a quarter of all reporting on domestic athletes in Finnish papers (32,6/129,0 pages). In the Turin 2006 Olympics, Finns won six silver and three bronze medals. Seven of the medallists were men. There was no comparable difference among Swedish athletes. ${ }^{2}$ When the gender distribution of domestic athletes' coverage in Finnish newspapers is correlated proportionately with the gender distribution of the number of Finnish athletes who participated in the Olympics and with their success, the gender distribution of the coverage can also be considered quantitatively equal (compare Hovden et al. 2010). Still, the limitation of research material to sports reporting on the Olympics should be emphasised. During Olympics women's sports receive much more coverage than usual in both Finnish and Swedish tabloids.

\section{Qualitative Research Results}

On an annual basis soccer and ice hockey are the two sports that are clearly allotted the most space in Finnish and Swedish tabloids. Particularly hockey is a typical example of a masculine team sport. The status of women's hockey is inferior in comparison to men's hockey. Space is allotted to women's hockey in Finnish and Swedish tabloids during Olympics, but otherwise it appears in papers very seldom. This was the primary reason that coverage of domestic male and female hockey players was included in the 
qualitative material. Initial thought was that coverage of a masculine sport would reveal a caricature demonstrating the difference between gender representations of male and female athletes.

A significant portion of the results of the qualitative analysis pertains specifically to newspaper coverage of hockey. That is handled first closely and after that the other main findings of the qualitative analysis are summarised.

Country-specific differences in coverage of domestic female hockey players were immense. In Swedish newspapers female hockey players were portrayed as athletes, not eye candy for men. In Finnish newspapers, they were trivialised in the text and sexualised in photos. Ojajärvi and Valtonen (2001), who studied how body image was depicted on the sports pages of Finnish tabloids during the Sydney 2000 Olympics and Paralympics, came to the same conclusion. In Olympics coverage bodies were inspected from all sides, but no matter the perspective, quantitatively weight always seemed to be considered too high or too low. Reporters poked fun at this by depicting the Olympics as a battleground for women with eating disorders. (Ojajärvi \& Valtonen 2001.)

Finnish papers' coverage of female hockey players back up researchers' interpretation, but on the other hand it is important to separate stories that sexualised the athletes from ones that alluded to eating disorders. Stories about female gymnast Svetlana Khorkina are typical examples of attention drawn to body weight both visually and verbally. This case, however, is not a matter of photography designed to provide eye candy for men but of critical coverage of the athlete's appearance, which had become sickly thin. It should also be noted that this type of coverage was not focused in particular on female athletes. Similar stories were published about male athletes in both countries. For example, stories about steroid use alluded to male hockey players' strong jaws and male swimmers' feet the size of flippers.

Conversely, Finnish newspapers' representations of female hockey players and the accompanying photos were highly sexual. The stories conveyed that female hockey players are thought of more as sexual figures than serious athletes (see Bernstein \& Blain 2003). The stories focused more on reporting about women's sexuality than about their athletic achievements (see Knoppers \& Elling 2004). For example, of the 14 photos of female hockey players published in the sports pages of Iltalehti, only four were from matches and the other ten were posed, sexualised photos. Of the sexualised photos five were taken in a studio and were used as the main photos in spreads. All those photos were taken by a male photographer and the stories written by a male reporter. The text set the tone for the sexualised depictions in the photos and slanted readers' own interpretations (compare Mäkelä 2007).

The subhead of an "Own Self" story about hockey player Saija Sirviö in Iltalehti proclaimed: It has not always been easy for Saija Sirviö to be a beautiful hockey player. The reporter summed up what was most relevant in the first paragraph. Hockey is a men's sport. Some feel is it not suitable for women, at least not for those who could be runway models instead of grappling in brawls on the ice. The spread included a photo almost as large as the page in which the Ice Queen is looking into the camera holding up hockey gloves to cover her bare breasts. The caption clarifies: Saija Sirviö knows how to act in a brawl, but also in front of a camera. In the main article the reporter sexualises the athlete's appearance using terms slim figure, sweet blonde and a female hockey player who takes care of her appearance. (Image 1.) When the media depicts female athletes 
who play masculine sports as fragile and sensual, it conveys a mental image that they are inferior to male athletes (Harris \& Clayton 2002). Hegemonic masculinity (see Connell $\&$ Messerschmidt 2005) is reproduced and reaffirmed (Messner 2002: 20).

Image 1. Image of Finnish hockey player Saija Sirviö published in Finnish newspaper Iltalehti (Feb 13th 2016)

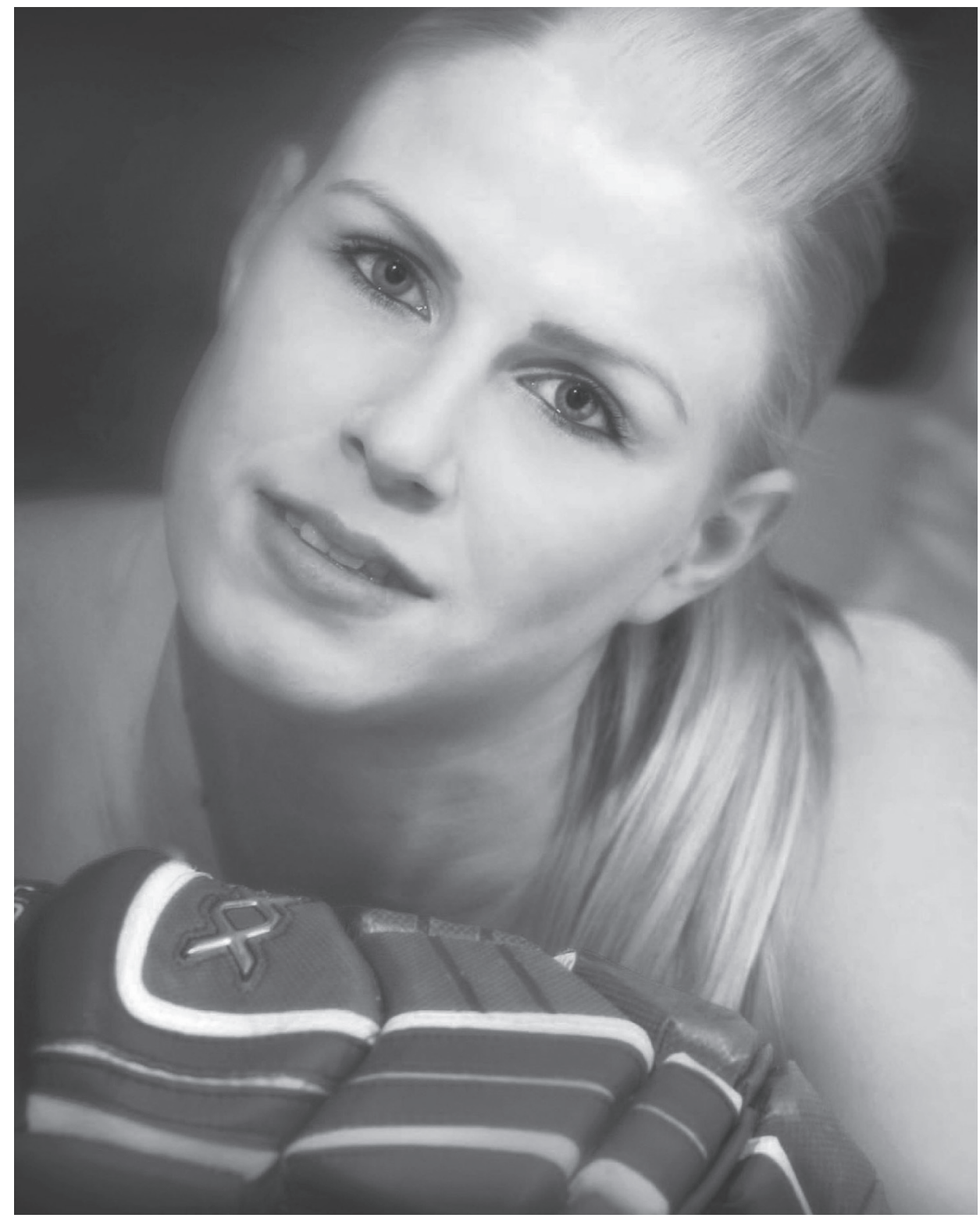

Note: Published with permission from Iltalehti for research purposes.

In one Ilta-Sanomat story questions presented to Finnish defender Emma Laaksonen by the reporter were: Why do women even play hockey? Does women's gear smell as bad as men's? What are women's testicle guards called? Apparently the youngest player on your 
team, Nora Räty, 16, has been given the pet name "baby." How do mothers and babies get along on the same team? Highlighting women athletes' dual role as mothers can be seen as a more frequent trivialising tendency (see Cooky et al. 2015; Kane et al. 2013).

Trivialising questions to male hockey players are not asked, and no sexualising studio photos of male players are to be found. Hardly have they even been asked to pose for such photos, and if they had, they would probably have refused. So why have female hockey players agreed to pose half-naked in front of camera? Is it a way for women playing a masculine sport to gain visibility in the sports media? According to a report published by the Sports Sponsorship Advisory Service, "Women should use more sex appeal to attract more media coverage and sponsors" (Brookes 2002: 143). Elite female athletes agree. Kane et al. (2013) explored how elite female athletes respond to the ways they are represented in sports media. Athletes were shown images ranging from on-court competence to off-court soft porn. Results indicate that competence was the overwhelming choice for "represents self/sport" and "increases respect". Nearly half of respondents picked soft porn to "increase interest" (Kane et al. 2013). Finnish female hockey players seem to have voluntarily adapted to this "increase interest" mould. Against this backdrop, there is reason to consider the problem posed by Mäkelä (2007). Can the media completely mould athletes into the kind of products they want? The researcher thinks not, as athletes' own actions can significantly affect how they are portrayed in the media. Examples of caricatures are erotic calendars aimed at increased visibility and financial gain (Mäkelä 2007). Pfister (2003) emphasises that female athletes are not victims. They themselves participate in the creation and sale of a certain type of image. Athletes are in many ways dependent on society, but can also affect its decisions (Pfister 2003).

But then, although women have turned toward an androgynous model in which physical strength and attractiveness are not considered binary opposites, the commercial publicity market in sports journalism does not always offer many alternatives (Pfister 2003; see also Messner 2002: 98-106). Even Iltalehti would hardly have published such large spreads about female hockey players if they had told the photographer, "Listen, buddy, how about you come to hockey practice to take your photos?"

On the other hand, it could be the athletes' desire to convey their heterosexual femininity, striving to avoid the prejudices and discrimination in the masculine world of hockey. They might try to adapt to hegemonic femininity. In general the idea behind it is that people have a more positive attitude towards women presenting themselves as heterosexually feminine, compared to those perceived as masculine. However, this equation is not simple. In case female athletes are considered to be too feminine, they are sexualised and trivialised. In other words, balancing seems to be a prerequisite for acceptance. Not all female athletes are keen for this, and some have started to resist hegemonic femininity. (Krane 2001; see also Krane et al. 2004.)

Some of the studies mentioned before examined Swedish sports media (see e.g., Koivula 1999; Wallin 1998), so they, too, have been shown to marginalise and trivialise female athletes. In this data such has been relatively minor, particularly when compared to the content in Finnish newspapers. In Swedish papers, female hockey players were represented as serious athletes, not sexual eye-catchers pandering to heterosexual men.

In Swedish papers, the majority of stories about domestic female hockey players were similar to those about domestic male players. For example, Aftonbladet published a spread about the Swedish women's hockey team with the headline: Here are our new 
heroes - clip and save the story. The story summarised facts about the athletes, analysed each player, reported their positions on the team and gave other details. It included two photos of each player, a larger one from a match and small headshot. (Image 2.)

Image 2. Images and facts about Swedish hockey player Katarina Timglas published in Swedish newspaper Aftonbladet (Feb 20th 2016)

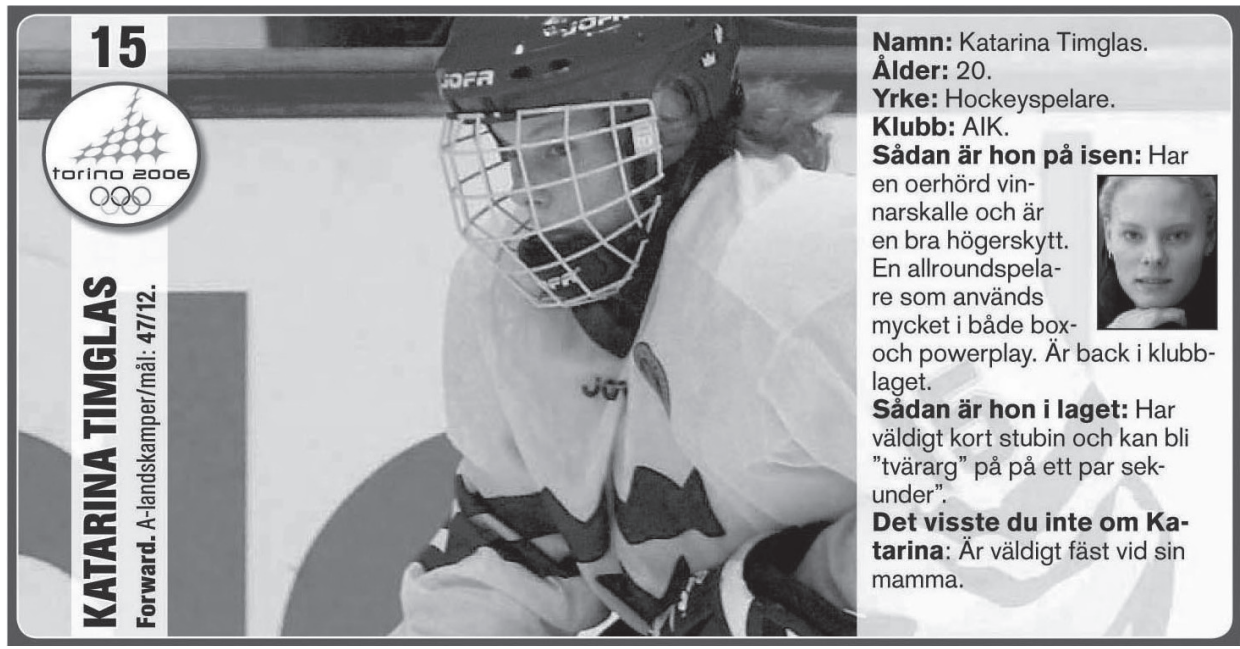

Note: Published with permission from Aftonbladet for research purposes.

Swedish papers published similar assessments of male and female athletes after hockey matches, but not once did Finnish papers assess women's achievements in the same way as men's. In a story in Expressen, the paper's female reporter Linda Johansson, for her part, indignantly expressed her opinion about how female hockey players were covered in other Swedish media. One of the subjects of her criticism was Dagens Nyheter sports reporter Johan Esk, who had written a few days earlier, Grown-up men celebrate women's hockey together. This sort of thing happened on a Friday in February 2006. Johansson wrote: I am saddened that I have so many comments about your way of writing about women's sports, Johan, but this is a question of some really bizarre things you have written...

The reporter has become known in Sweden for her feminist opinions (see e.g., Carlsson 2003) and the story in question was written from a feminist, caricaturised viewpoint. In any case it conveys how seriously Swedish tabloids take women's hockey. And this was not the only such story. Swedish papers published also other editorial pieces in defence of female athletes. Dahlén (2008: 479) made a similar observation regarding an editorial in Aftonbladet about the 2007 European Wresting Championships.

Up to this point analysis of qualitative material has emphasised gender representation in sports traditionally considered masculine. The second main finding of the qualitative analysis is that research stereotypes showing that trivialisation and sexualisation focus on female athletes should in other cases be approached with reservation. For the most part, gender representations of male and female athletes in Finnish and Swedish newspapers were similar.

In the majority of stories female athletes were trivialised no more than male athletes. Tabloids are consumer entertainment products that include photos of scantily-clad athletes 
and trivialising language. The choice of words often conveys a caricature, or is critical or humorous. Electronic media and morning papers have already reported results and summaries of matches. As entertainment journalism, tabloids must offer something different. At the same time athletes' bodies are sexualised and turned into media objects. Still, it would be an exaggeration to assert that sexualising photos and trivialising language are focused only on females (see e.g., Ojajärvi \& Valtonen 2001; Wickman 2006). And it would be an equal exaggeration to generalize that Finnish tabloids discriminated against women's sports. Women's hockey provides a caricature of the differences between Finnish and Swedish tabloids, but does not brand the content of Finnish tabloids.

For the most part, women's sports were covered pertinently in Finnish papers, as well. Overall, sports journalism in Swedish papers was more egalitarian, but the differences were not comparable to those seen in coverage of women's hockey. Mäkelä (2007) believes that through development of gender equality in Finnish society overall women have solidified their position in sports, as well. According to Tervo (2002), the 21 st century has brought with it changes in the masculine culture of sports. She feels that a Finnish athlete can be a national hero, in the way that tears shed by a male athlete have been made the tears of the entire nation. Kinnunen (2003), who studied representation of men's bodies in Finnish television sports journalism, writes that a new kind of sports hero not only achieves peak performances, but also looks like a peak performer. Alongside the taciturn athletic achiever, masculinity is modelled on a pleasant public demeanour and a flawless appearance (Kinnunen 2003).

\section{Conclusions}

Based on quantitative and qualitative analysis of gender representations in Olympics coverage in Finnish and Swedish tabloids, the most radical gender stereotypes have crumbled. Excessive generalisations about the amount and content of men's and women's sports coverage should be avoided, even though male athletes did receive more coverage than females (see also Hovden et al. 2010). Male and female athletes were covered mainly equally. However, Finnish newspapers heavily trivialised and sexualised female ice-hockey players, but in Swedish newspapers female hockey players were represented as serious athletes. Country-specific differences were so immense that reasons needs to be discussed.

Central reason is that the everyday status of women's team ball sports is clearly better in Swedish sports media. For example outside major sports events like Olympics in Finnish tabloids the reporting of two most covered ball sports, soccer and hockey, concentrates almost solely to men. Rarely even results from women's matches are listed. And because it is not normal to cover women in those sports, when women are covered, approach easily turns out to be trivialising. In Swedish tabloids women's ball sports reporting is also marginal, but anyway regular. Especially women's soccer is covered. As Dahlén (2008) points out Swedish sports media have actually promoted the status of women's soccer and thus furthered equality in sports. Visibility has increased and reporting has become more equitable. (Dahlén 2008: 484-485.) And as one women's ball sport has been covered seriously, others are covered too - even though year-round rarely.

Why Swedish tabloids then cover women's ball sports seriously, but the Finnish ones do not? This might be a remnant of the fact that in many fields of life, Swedish society 
can historically be considered more equal and progressive than Finnish society. Many reforms in Finland have followed Sweden's lead. For example, the emancipation of women in competitive sports occurred earlier and more painlessly in Sweden than in Finland. However, the cultural-historical context of the two countries is too extensive and complex for it to be discussed in this work. Instead the question is examined from the perspective of the news criteria of sports journalism.

The core news criterion is the general interest for a sporting event. Central gauges used to evaluate the general interest are attendance average on the events and amount of television viewers (Wallin 1998: 77-78; Laine 2011: 105-132). Only those sports visible on television have achieved a regular following by the tabloids. In Sweden, the attendance average of women's top league soccer increased considerably in the early $21^{\text {st }}$ century, partly due to the international success of the women's national soccer team. During the first data year of this study (2004), the attendance average was 1147, and at its best, a single match had nearly 9000 spectators. As the number of spectators increased, also the television became interested. Subsequently, the television presence has increased, and for example in 2015, all soccer matches in the women's top league were broadcast live for the first time on television or online. During 2004 in Finland the attendance average for the women's top league soccer was only 111 and even smaller in ice hockey: 97 . No women's top league hockey matches are broadcast on Finnish television, and even the women's top league soccer matches are broadcast only a few times a year, at most. And because the women's national league matches of either of the two most-followed sports in the Finnish media attract spectators, and because the matches are not shown on television, they have decent visibility in the tabloids only during major sporting events. And in this case, the approach is often such that it trivialises and sexualises women.

Lastly, as the text is being finalised, the data is around ten years old. However the results are still valid. Some changes have occurred over the past decade, particularly in Finnish newspapers that follow their Swedish colleagues in many ways (Laine 2011: 323-324), but the gender representations in sports media have not changed considerably.

\section{Notes}

1. In the comparison, each medal is counted as only one medal regardless of whether it was won by an individual, a pair or a team.

2. In the Athens 2004 Olympics, Swedish men won four medals (three gold and one silver), women won two medals (one gold and one bronze) and a mixed-gender team won a silver medal. In the Turin 2006 Olympics, Swedish men won five medals (three gold and two silver) and women won nine medals (four gold, two silver and three bronze).

\section{References}

Bernstein, Alina (2002) Is It Time for a Victory Lap? Changes in the Media Coverage of Women in Sport. International Review for the Sociology of Sport 37(3-4):415-428.

Bernstein, Alina \& Blain, Neil (2003) Sport and the Media: The Emergence of a Major Research Field. In Bernstein, Alina \& Blain, Neil (eds) Sport, Media, Culture: Global and Local Dimensions, 1-30. London: Frank Cass.

Brookes, Rod (2002) Representing Sport. London: Arnold.

Carlsson, Ylva (2003) Linna Johansson vägrar tycka likadant. Pressens Tidning 84(16):24-27.

Crossman, Jane, Vincent, John \& Speed, Harriet (2007) ‘The Times They are A-Changin'. Gender Comparisions in Three National Newspapers of the 2004 Wimbledon Championships. International Review for the Sociology of Sport 42(1):27-41. 
Connell, R. W. \& Messerschmidt, James W. (2005) Hegemonic Masculinity. Rethinking the Concept. Gender \& Society 19(6):829-859.

Cooky, Cheryl, Messner, Michael A. \& Hextrum, Robin H. (2013) Women Play Sport, But Not on TV: A Longitudinal Study of Televised News Media. Communication \& Sport 1(3):203-230.

Cooky, Cheryl, Messner, Michael A. \& Musto, Michela (2015) “It's Dude Time!”: A Quarter Century of Excluding Women's Sports in Televised News and Highlight Shows. Communication \& Sport 3(3):261-287.

Dahlén, Peter (2008) Sport och medier. Kristiansand: IJ-Förlaget.

Duncan, Margaret C. \& Messner, Michael A. (2005) Gender in Televised Sports: News and Highlight Shows, 1989-2004. Los Angeles, Ca: Amateur athletic foundation. Available at: http://www.la84foundation. org/9arr/ResearchReports/tv2004.pdf (accessed 2 May 2015).

Eastman, Susan T. \& Billings, Andrew C. (2000) Sportscasting and Sports Reporting. The Power of Gender Bias. Journal of Sport \& Social Issues 24(2):192-213.

Flick, Uwe (2009) An Introduction to Qualitative Research. $4^{\text {th }}$ edition. Thousand Oaks, CA: Sage.

Harris, John \& Clayton, Ben (2002) Feminity, Masculinity, Physicality and the English Tabloid Press. The Case of Anna Kournikova. International Review for the Sociology of Sport 37(3-4):397-413.

Hovden, Jorid, Bruce, Toni \& Markula, Pirkko (2010) The Big Picture: Data Comparisons and Implications. In Bruce, Toni, Hovden, Jorid \& Markula, Pirkko (eds) Sportswomen at the Olympics. A Global Content Analysis of Newspaper Coverage, 289-304. Rotterdam: Sense.

Kane, Mary Jo, LaVoi, Nicole M. \& Fink, Janet S. (2013) Exploring Elite Female Athletes' Interpretations of Sport Media Images: A Window Into the Construction of Social Identity and "Selling Sex" in Women's Sports. Communication \& Sport 1(3):269-298.

Kinnunen, Taina (2003) Kansakunnan sotureita ja ihannevartaloita - television urheilu-uutisten miesruumiin representaatiot. Lähikuva 17(1):16-29.

Knoppers, Annelies \& Elling, Agnes (2004) ‘We Do Not Engage in Promotional Journalism'. Discursive Strategies Used by Sport Journalists to Describe the Selection Process. International Review for the Sociology of Sport 39(1):57-73.

Koivula, Nathalie (1999) Gender stereotyping in televised media sport coverage. Sex roles 41(7/8):589-604.

Koivula, Nathalie (2000) "Kämpa nu gubbar!” Om könsfördomar i sportbevakning. JMG Granskaren $3(1): 18-21$.

Koivula, Nathalie (2001) Perceived Characteristics of Sports Categorized as Gender-Neutral, Feminine and Masculine. Journal of Sport Behavior 24(4):377-393.

Krane, Vikki (2001) We Can Be Athletic and Feminine, But Do We Want To? Challenging Hegemonic Femininity in Women's Sport. Quest 53(1):115-133.

Krane, Vikki, Choi, Precilla Y. L., Baird, Shannon M., Aimar, Christine M. \& Kauer, Kerrie J. (2004) Living the Paradox: Female Athletes Negotiate Femininity and Muscularity. Sex Roles 50(5/6):315-329.

Krippendorf, Klaus (1980) Content Analysis. An Introduction to Its Methodology. Beverly Hills, Ca.: Sage.

Krippendorf, Klaus (2004) Content Analysis. An Introduction to Its Methodology. $2^{\text {nd }}$ edition. Thousand Oaks, Ca.: Sage.

Laine, Antti (2011) Urheilujournalismin Suomi-Ruotsi-maaottelu. Vertaileva tutkimus suomalaisten ja ruotsalaisten iltapäivälehtien Ateenan 2004 ja Torinon 2006 olympiauutisoinnista. Helsinki: Edita.

Larsson, Håkan (2003) Idrottens genus. Idrottsforum.org 22 June 2003. Available at: http://www.idrottsforum. org/articles/larsson/larsson.html (accessed 24 March 2015).

Lehtinen, Tiina-Liisa (2006) Nais- ja miesurheilijan representointi Helsingin Sanomissa vuoden 2004 Ateenan olympialaisten kontekstissa. Jyväskylän yliopisto. Kielten laitos. Suomen kielen pro gradu -tutkielma.

Lumpkin, Angela (2009) Female Representation in Feature Articles Published by Sports Illustrated in the 1990s. Women in Sport \& Physical Activity Journal 18(2):28-51.

Markula, Pirkko (2009) 'Acceptable Bodies': Deconstructing the Finnish Media Coverage of the 2004 Olympic Games. In Markula, Pirkko (ed.) Olympic Women and the Media, 87-111. Basingstoke: Palgrave Macmillan.

Messner, Michael A. (2002) Taking the Field. Women, Men, and Sports. Minneapolis: University of Minnesota Press.

Messner, Michael A., Duncan, Margaret C. \& Cooky Cheryl (2003) Silence, Sports Bras, And Wrestling Porn. Women in Televised Sports News and Highlights Shows. Journal of Sport \& Social Issues 27(1):38-51.

Mäkelä, Annu (2007) Muuttuva naiskuva: naisyleisurheilu Helsingin Sanomissa vuosien 1983 ja 2005 MM-kisoissa. In Roiko-Jokela, Heikki \& Sironen, Esa (eds) Vanhat mestarit. Suomen urheiluhistoriallisen seuran vuosikirja 2007, 73-85. Helsinki: Minerva.

Ojajärvi, Sanna \& Valtonen, Sanna (2001) Naisten lentopallo, asiaa! Journalismikritiikin vuosikirja 2001/ Tiedotustutkimus 24(1):19-26.

Pfister, Gertrud (2003) Kaupan paljasta pintaa - Anna Kournikova ja urheilu tavarana. In Roiko-Jokela, Heikki \& Sironen, Esa (eds) Kynäniekkoja, kivinyrkkejä, mäki-matteja. Suomen urheiluhistoriallisen seuran vuosikirja 2003, 152-166. Jyväskylä: Atena. 
Pirinen, Riitta (2006) Urheileva Nainen lehtiteksteissä. Tampereen yliopisto. Acta Universitatis Tamperencis 1138.

Rowe, David (1998) Play Up. Rethinking Power and Resistance in Sport. Journal of Sport \& Social Issues 22(3):241-251.

Schreier, Margrit (2012) Qualitative Content Analysis in Practice. Thousand Oaks, CA: Sage.

Steinke, Ines (2004) Quality criteria in qualitative research. In Flick, Uwe, von Kardorff, Ernst \& Steinke, Ines (eds) A companion to qualitative research, 184-190. London: Sage.

Tervo, Mervi (2002) “Havuja, perkele!” Sukupuoli, sankaruus ja kansallinen identiteetti suomalaisessa urheilu-uutisoinnissa. Nordia Tiedonantoja 1:64.

Titscher, Stefan, Meyer Michael, Wodak, Ruth \& Vetter, Eva (2000) Methods of Text and Discourse Analysis. Thousand Oaks, CA: Sage.

Tolvhed, Helena (2010) Sweden. In Bruce, Toni, Hovden, Jorid \& Markula, Pirkko (eds) Sportswomen at the Olympics. A Global Content Analysis of Newspaper Coverage, 61-72. Rotterdam: Sense.

Wallin, Ulf (1998) Sporten i spalterna. Sportjournalistikens utveckling i svensk dagspress under 100 år. Göteborgs universitet. Göteborgsstudier i journalistik och masskommunikation 16.

Wickman, Jan (2006) Mediaseksikäs miesurheilija. In Kinnunen, T. \& Puuronen, A. (eds) Seksuaalinen ruumis, 143-159. Helsinki: Gaudeamus.

ANTTI LAINE, Ph.D., Postdoctoral Researcher, The Department of Sport Sciences, Unit of Social Sciences of Sport, University of Jyväskylä, antti.laine@jyu.fi 